\title{
An Analysis of EFL Students' Questions in Research on ELT Class at University of PGRI Ronggolawe Tuban
}

\author{
Aisah Asariski' ${ }^{1}$, Christina I.T. Panggabean ${ }^{2}$ \\ Universitas PGRI Ronggolawe Tuban, Indonesia \\ 1aasariski@gmail.com, ${ }^{2}$ christina306.cp@gmail.com
}

\begin{abstract}
This article reported the questions applied by EFL students in Research on ELT (English Language Teaching) Class at University of PGRI Ronggolawe Tuban. This research was conducted to know the types of questions applied by the students, the most dominant questions used by adopting the cognitive domains of Bloom's taxonomy, and the students' responses towards the questions. Descriptive qualitative research design was applied in the research. The subject of the research were the sixth semester students taking Research on ELT course. To collect the data,observation using Telegram application and interview were applied. The data were analyzed qualitatively to determine the cognitive level of each question according to revised Bloom's taxonomy. Based on the data analysi, itdemonstrated that the students used empirical questions as the type of questions. The dominant question used related to the cognitive domains of Bloom's taxonomy was Analyzing level or C4 which appeared 48\%. It showed that HOTS questions were the most used at the classroom with the total $64 \%$, while the LOTS questions only got $36 \%$. The students claimed that they felt interested and glad to answer the questions. It can be concluded that the students of Research on ELT class had shown that they had ability to think critically.
\end{abstract}

Keywords:Question, Higher Order Thinking Skills (HOTS), Lower Order Thinking Skills (LOTS), Classroom presentation.

\section{INTRODUCTION}

Teachers have an important role in controlling and managing the class so that students who are passive can be more activein classroom activities. White and Lightbown (Toni \& Parse, 2013) stated that teachers tend to be the most dominant in the class, determine the topics, lead the exchange of talks, and become the main person who ask questions. In addition, besides providing questions, teachers tend to assist their students to answer. In the classroom, the use of questioning skills is included for any objectives of their teaching. Furthermore, it is important to realize that it is not only the students' ability in speaking and expressing themselves that should be taken into consideration but also various types of involvement in classroom participation including teacher-student, student-teacher, student-student, group work, etc. Walsh (2013) delineated interaction as a form of communication which needs the competency of all people involved in it.

Questioning is a kind of the general techniques employed by teachers or lecturers.It is a fact that question and answer activitiestended to dominate the class time and applied

Aisah Asariski, Christina I.T. Panggabean| 13 An Analysis of EFL Students' Questions in Research on ELT Class 
by teachers in their interaction with the students (Richards and Lockhart, 2007). Meanwhile, Farmer (2006) asserted that question is a skill that can link to what is unknown to what is known.Based on that it is essential asking questions should be parts of classroom activities for the students to practice.classroom activities for the students to practice.

Tsui (1992: 89) mentioned that questions are divided into three main groups: which include (1) Yes/No questions, (2) WH-questions and (3) Alternative questions. In Yes/No questions, we usually form the question by putting auxiliary before subject and use rising intonation (e.g. Do you like it?). Meanwhile, in WH-questions, we use Whwords and use falling intonation (e.g.Whatdo you do in your free time?). And the last is Alternative questions, in which options are provided. This type of questions can occur in Yes/No questions or WH-questions(e.g.Do you want to do the task individually or in group? or Which one do you like as your birthday present: a cellphone, a bicycle, or sneakers?).

There are also convergent and divergent questions proposed by Gabrielatos (1997). These kinds of questions are differenciated by the expected responses. When the teacher expects the students to give one correct answer for his/her question, the question is categorized as convergent question (e.g.What is the highest mountain in the world?). On the other hand, a divergent question is the question expecting the students to deliver their views or values.This kind of question can be answered with more than one answer.

Moore (2001) proposed a classification of questions based on taxonomy of learning. Bloom (1956: 18) firstly introduced his taxonomy and later Anderson and Krathwohl (2002)proposed a revision. They are factual questions, empirical questions, productive questions, and evaluative questions. Factual questions are questions asked to recall information (e.g. Who is the main character of the novel?). Empirical questions are questions asked in order that students are expected to integrate or analyze given or recalled information (e.g. How do you know?). Productive questions direct students or learners to think creatively and produce something unique (e.g. How will you make the fruit to get more money?). Evaluative questionsexpect students or learners to make judgements or state values (e.g. What is the best way among the three to solve your present problem with your parents?). The division of questions ranging from lower to higher levels of cognitive thinking is provided by Bloom's taxonomy.

In education world, students need to possess higher order thinking skill in order to solve problems and face challenges. Higher order thinking skill demands students to be capable of analyzing, evaluating, and creating ideas to face problems both at school and in their social lives. According to Brookhart (2010),higher order thinking skill provides advantages for students to be able to improve their achievement and raise their motivation. Newmann, Bryk, and Nagaoka (in Brookhart, 2010: 11) clarified that students with higher order thinking are provided with several useful and essensial skills to solve problems. They are capable of organizing their knowledge and experience and elaborating their statements or opinions. In addition, students who are provided with higher order thinking will be more motivated in their learning.Moreover, they are more creative to solve problems with good, creative, and relevant ideas that will be useful for daily life. Students or learners are also more creative in solving a problem.

Brookhart (2010, p.5-8) specified higher order thinking skills into three functions: as transfer, as critical thinking skills, and as problem solving. Students with higher order thinking skill have the ability to comprehend information since they employ critical 
attitudes, evaluation, awareness, and problem solving skills(Mc Loughlin and Luca (in Widodo and Sri (2013, p.162). It is presented with the Bloom's definition about the aspects of thinking both in LOTS and HOTS. The first three levels which are Remember, Understand and Apply are categorized as Lower-Order Thinking Skill. Meanwhile, Mishra \& Kotecha (2016) stated the Bloom's revised taxonomy gave information about HOTS, which constitute analyzing, evaluating, and creating.

Some previous studies reported the implementation of HOTS. Mahfuzah (2019) reported the Students' Ability in Answering Reading Questions applying HOTS.Her study explained the ability of the students to answer reading questions having HOTS and theirmistakes in answering the questions.Another previous study is from Kartika (2019), who reported the use of higher-order thinking skill (HOTS) questions in National Examination for English subject were insufficient.Meanwhile, Dewi (2018) analyzed questioning strategies employed by lecturer in Reading Class.The reportmentioned that there were fifty questions delivered by the lecturer. The result showed that the most dominant questions proposed by the lecturer was Evaluating or C3 with the total 48\% from 50 questions. Remembering or C2 category appeared $10 \%$, Understanding $32 \%$, and $5 \%$ of Creating. While other skills like Analyzing and Applying got $0 \%$ distribution. It can be concluded that the lecturer's questions had HOTS category.

In this present study, the higher order thinking skill theory of Bloom's taxonomy consisting of analyzing, evaluating, and creating skills revisedby Krathwol and Anderson were applied.However, the difference of this study from the previous studies is the subject which is used by the other researchers. If the other researchers mostly focused on the textbook and the teachers' questions to be analyzed. In this research, the researchers wanted to investigate to what extent analyzing, evaluating, and creating skill level are applied by the students in asking questions in the discussion session of presentation in Research on ELT class.Higher order thinking is emphasized in higher education in which students are expected to be active inevaluating ideas and information (Bassham, et al., 2005). Through higher order thinking skill, the students' critical thinking ability is activated. Considering the importance of critical thinking skill showed from the questions asked by the students, this study was conducted.

This research has three main research questions: What type of questions do the students apply in classroom presentation?, What is the most dominant questions apllied by the students?and What are the students' responses towards the questions asked?This research is expected to contribute some insight for teachers or lecturers to enhance the students' questioning skill through relevant tasks such as classroom presentation.

\section{METHOD}

This studyuseddescriptive qualitative research design chosen due to the type of the study which is to analyze the students' questions in Research on ELT (English Language Teaching ) class.

The questions and responses from the college students in Research on ELT ( English Language Teaching ) class became the data of the study. The subject of this study werethe Sixth semester students in the academic year 2019/2020 at University of PGRI Ronggolawe (UNIROW) Tuban.The data were collected through observation for four meetings and interview. Firstly, the activities during presentation were observed through Telegram group for Research on ELT course;secondly, the questions from the discussion session were recorded; and thirdlysome students were interviewed to know 
their responses towards the questions asked in the presentation. Meanwhile for the data analysis, several steps were applied: (1) Identifying questions, (2) Coding the questions, (3) Classifying the questions into each level of the revised version of Bloom's taxonomy, (4) Describing the questions types and the most dominant one, (5) Transcribing the recorded interview, (6) Describingthe students' responses toward the questions, (7) Describing all the data in narrative form, and (8) Concluding.

\section{RESULTS}

Type of questions asked by the college students in Research on ELT ( English Language Teaching ) class.

The researcher uses the theory from Anderson and Krathwol (2002) to classify the type of questions based on the taxonomy learning.

From four meetings, there are fifty questions from the college students asked at discussion session on online class through Telegram application. As it is shown in the table below, there are 4 types questions appeared on the online class. Empirical questionsoccuredthe most frequently, that is 30 times or $60 \%$.

Table 1. The Types of Questions Performed by The College Students.

\begin{tabular}{llcc}
\hline No. & Type of questions & Occurences & Precentage \\
\hline 1. & Factual questions & 12 & $24 \%$ \\
2. & Empirical questions & 30 & $60 \%$ \\
3. & Evaluative questions & 6 & $12 \%$ \\
4. & Productive questions & 2 & $4 \%$ \\
\hline \multicolumn{2}{c}{ Total } & 50 & $100 \%$ \\
\hline
\end{tabular}

The finding shows that the questions used by EFL students has more complex thinking process than the former of recalling and understanding. This kind of questions show that the college students are able to breaking material. However applying, assessing, integrating and problem solving are often used by the college students than recalling and understanding facts which include on factual questions.

\section{The most dominant question applied by the students}

The following table shows the data related to the number of occurences of cognitive domains employed in the students' questions.

Table 2. The Cognitive Domains Employed in College Students' Questions

\begin{tabular}{clcc}
\hline No. & Cognitive domains & Occurences & Percentage \\
\hline 1. & Remembering & 4 & $8 \%$ \\
2. & Understanding & 9 & $18 \%$ \\
3. & Applying & 5 & $10 \%$ \\
4. & Analyzing & 24 & $48 \%$ \\
5. & Evaluating & 6 & $12 \%$ \\
6. & Creating & 2 & $4 \%$ \\
\hline & Total & $\mathbf{5 0}$ & $\mathbf{1 0 0} \%$
\end{tabular}


Table 2 shows that questions with analyzing category become the first which occurs 24 times (48\%). Creating category occurs 2 times (4\%). Remembering categoryoccurs 4 times (8\%). While understanding category occurs 9 times (18\%). Whileapplying category with total occurence is 5 times (10\%) and evaluating category has 6 times $(12 \%)$ appearances. The table shows that higher-order questions are in the highest position, which occur 32 of 50 questions. Lower-order questions only occur 18 times. Based on that, the questions have developed the college students' reasoning and problem solving.

The first level is remembering or $\mathrm{C} 1$, this level has fewer question than understanding level. There are 4 questions or $8 \%$ appeared in the discussion time. This level relates to information retrieval and highly associated with memory ( Bloom, 1956 ). While, Krathwohl (2002) assured that remembering cognitive process appeared in questions recalling information. The example question based on the college students question like, "What kind of materials does require the use of intructional media to make the teaching effective?". That question implies to mention the answer like an operational verb that is at the level of remembering. The next as the second level is understanding skill or C2 gets the highest position among the three skills in the lower order thinking level. The following is the example question from $\mathrm{C} 2$ level, "What is meant by the development of micro and macro reading competencies?" , that question includes in understanding level or C2 because to answer it we need to explain what it means. Meanwhile "Explain " includes in $\mathrm{C} 2$. Understanding level happens because the questions contain answers that are in the material and do not require further reasoning.

The third level is applying or C3, it performed fewer than the level before only 5 questions or $10 \%$. This level applying previously learned information ( knowledge ) to new and unfumiliar situations. The example taken such as, "How does the teacher utilize the instructional media in the classroom? " that question comprise word "utilize" which has the same meaning with "use", it include in the operational verb on the C3 or applying level.

Furthermore, the forth level is analyzing skill or C4 gets the highest position among the three skills in the higher-order thinking level. The example of the analyzing question from the students like, "Why it is important to build good interaction between teachers and students?" this questions contains the reasoning explanation on the answer. Brookhart (2010) also points out that at the analysis level, we are talking about finding the main idea in a text that does not state the main idea explicitly.

The following level is evaluating skill as the fifth level or C5 which obtains six questions or $12 \%$. The researcher takes the example as follows, "If in the speaking class. Should the teacher used L1?" from that question, it has meaning that the question asks to give the confirmation and defense based on the material. Brookhart (2010) states that evaluation can be stated as a conclusion and supported with evidence and logic.

The last category is creating skill or $\mathrm{C} 6$ which has the least number of appearances with the total 2 questions or $4 \%$. Creating skill is reorganizing elements into a new pattern or structure. The example question like, "Based on your opinion, which one is the most effective coomunication strategies? Explain why! “ .

\section{The students' responses toward HOTS questions through interview}


The researcher took four students to be interviewed in order to know their responses toward the questions asked.This question focused on the college students' responses when they gave or got the higher-order questions.

The interview took during the Covid-19 pandemic on 18th of July 2020, so that the interview was conducted online through WhatsApp (WA) application. The following is the data interview from four college students of Research on ELT class. The data interview from student 1 showed she always needed more time to answer the higherorder questions, especially on evaluating and creating category and sometimes she felt difficult to answer it. While from the student 2, the researcher got the data that she tried to answer the higher-order questions as much as possible, although sometimes it felt difficult to answer the question with the higher-order thinking because she sometimes did not understand well with the topic, so that she got the difficulties. Student 2 thought that the evaluating level was the difficult one of six cognitive domains, because she had to make a judgement about the values of ideas, item and material when answering the questions. Meanwhile, student 3 stated that she felt interested when her friends asked her with the higher-order questions, although she got the difficulties to answer the HOTS question and needed logical thinking which requires a reasoning process but she felt that it was able to improve her knowledge more. Student 3 took analyzing and evaluating as the difficult domain level of revised Bloom's taxonomy, because she usually got difficulties to answer it. Furthermore, the data interview from student 4 represent that she was glad when she got the HOTS questions.She thought it gave her an opportunity to explore more the knowledge which had not known so she could deliver, and gave new knowledge to the audiences. Student 4 also claimed that she got the difficulties when facing the higher-order questions, but it was worth for her. She stated that the difficult one of cognitive domain from Bloom's taxonomy was analyzing. Because to answer the questions which are in the analyzing level, we had to really understand first about the material. From the students' responses, it shows thathigherorder questions helped them expand their knowledge even further and made them feel challenged to answer it.

\section{DISCUSSION}

Based on the findings reported above, there are four types of questions occurring in the students' questions. There are factual questions, empirical questions, evaluative questions, and productive questions. These four types of questions are related to Anderson and Krathwol (2002) taxonomy of learning. The findings showed that the students asked more complex questions since factual questions considered as the lower order thinking skill only reached $24 \%$. Meanwhile, the other questions cover empirical questions (60\%), evaluative questions (12\%), and productive questions (4\%).

Factual questions require the learners to simply recall the information. This type questions reinforce the learners' memory of what has been learnt before. Thecollege students then process the informations by matching facts and basic knowledge exist in their mind to produce a response toward the questions. Even though it involves a cognitive process to deal with, this questions merely calls for a single correct answer. It can be inferred that it only includes lower-order thinking. Based on the findings above, the factual questions appear 12 times (24\%). This does not dominate and covers up the occurences of other types of questions.

Empirical questions require the learners to integrate or analyze given informations. This type of questions retrievals and use remembered informations to produce the 18|ENGLISH EDUCATION Journal Of English Teaching and Research 
answer of questions expressed. Based on the findings above, empirical questions appear 30 times $(60 \%)$. As this type of questions commonly calls the learners or the college students to reach beyond simple memory, it implies that this type of questions encourage a higher level of the learners' thinking skill.

Evaluative questions, as the name suggests, are the questions which lead the learners to put values or make a kind of judgement based on certain criteria. The learners need to consider the criteria in a complex process, which involves some combination of previous taxonomies, before arriving at some judgements. This complex process engages higherorder questions and quite frequently entails some utterences preceding the evaluation one. Based on the findings, evaluation category appear 6 times, or only $12 \%$ of total questions performed during dicussion time at Research on ELT class. It implies that only a few questions cope with higher-order thinking.

The highest level of questions is productive category. This relates to the cognitive process of working with elements and combining them to constitute a pattern which is not clearly stated before. A practice of constituting a pattern itself is beyond here and now in meaningful ways that allows for explorations and thus it can be inferred that productive question works within complex level of thinking. According to the findings, it occurs 2 times or $4 \%$ and belongs to the last position for the dominance. Its total is fewer than other types of questions.

Regarding the most dominant questions, the result of the data shows that all questions which are categorised higher order thinking skills reached 64\%. It means the higher order thinking skill is higher than lower-order thinking skill. Based on the analyzed data, the higher order thinking skill that was employed by the students in Reseach on ELT class is the analyzing skill (48\%). Although this research has different subject from the previous study byMahfuzah (2019), the result of this research has similarity with the previous study about the students' ability in answering reading questions with HOTS. The result of both the research showed that HOTS ( Higher Order Thinking Skill ) had the highest distribution than LOTS ( Lower Order Thinking Skills ). Other similarity is from Dewi (2018). The research showed HOTS questions as the dominant questions in reading class, whose total occurances reached $53 \%$.

From the previous studies, almost the most HOTS distribution uttered by the teachers or the lecturers. Meanwhile, HOTS questions that were producedby students were still rare. At the university level, the students should have critical thinking skill. However, it cannot be separated from the attempt of the teachers or lecturers to keep encouragingthe students to ask questions in HOTS level. It may be obtained from the lecturers' questions which have been critical from the start, by frequently having indepth discussions, or even by frequently being given assignments and then presenting them.Indirectly, it can encourage students to activate their critical thinking.

It is a fact that higher order thinking skill questions are not easy to ask and to answer. Based on the results of interview the students mentioned that analyzing, evaluating, and creating are considered difficult. Daiek \& Anter (2004)claimed that question in level creating had difficulty in answering.The question encourages us to create and build our own opinion based on ourselves, so that it is categorized into the creating skill level. This question also invites the learners to produce original ideas and solve problems. However, the students were encouraged to answer the questions that would proved their knowledge and mastery of the topic presented or discussed. 
It is in line with Bassham, et al. (2005) who claimed that the higher order thinking skill plays a vital role throughout the learning process because it could improve students' ability in critical thinking skill to evaluate the information.

\section{CONCLUSION}

From the finding, thestudents of Research on ELT class employed four types of questions. They are factual questions, empirical questions, evaluative questions, and productive questions. The most frequent question is the empirical questions. The cognitive domains belong to the empirical type questions are applying and analyzing. Those domain belongs to the higher-order thinking skill, which emphasized on breaking material. It proves that the students used more higher order questions instead of the lower order questions. The researcher found analyzing skill or C4 which include on the HOTS level as the dominant questions used by the students. It is proven by the highest total shown in the data analysis as much 64\%. It shows that the higher-order thinking skill (HOTS) questions has been applied at the class. The college students of Research on ELT class have the ability to think critically. Furthermore, the result of data interview was found that the college students' responses toward the higher-order thinking skills (HOTS) has some variation. But most of the interviewed students liketo be asked and more eager to answer the higher-order questions, because it was considered challenging and could help them to explore further knowledge.

Referring to the findings, it is suggested that the students can use this study as a reference or material regarding questions. They are expected not only to give questions critically, but also to be able to respond critically, especially to solve the problem given.For further researchers, they are suggestedto do similar research for different subjects and may further study on the quality of the students' questions and responses, whether the questions and the answers were relevant to the topic discussed. Besides, they also can study the teacher or lecturers' questions in classroom interactions to know whether their questions encourage the students to think critically.

\section{REFERENCES}

Anderson, et al. (2001) .A taxonomy for learning, teaching, and assessing: A revision of Bloom's taxonomy of educational objectives. New York:Longman.

Bassham, Gregory, Irwin W., Nardone, H., \& Wallace, J. (2005). Criticalthinking: A student's introduction. New York: McGraw Hill.

Bloom, B. S. (1956). Taxonomy of educational objectives: The classification of educational goals.Handbook 1; Cognitive Domain.

Brookhart, Susan M. (2010). How to assess higher-order thinking skills in your classroom.Virginia, USA: ASCD.

Daiek, Deborah \& Anter, N. (2004). Critical reading for college and beyond. Boston:The McGraw-Hill Companies.

Dewi, Puspa. (2018). The analysis of questioning strategies used by lecturer in reading class,

(Online),vol.2.(http://jurnal.unimus.ac.id/index.php/ELLIC/article/view/3546/, accessed on 23 August 2020.

Farmer, L. S. J. (2006). What is questioning? Paper presented at conference in world library and information congress: on questioningSeoul, Korea. Retrieved from http://www.ifla.org/Vifla72/index.htm.on 23 August, 2020. 
Gabrielatos, C. A Question of functions: Teacher questions in the EFL classrooms. Retrieved from https://www.researchgate.net/publication/261708658 A question of function Teacher questions in the EFL classroom on 23 August, 2020.

Kartika, Tomy, DebigaFikky Abdullah. 2019. Higher order thinking skill (HOTS) questions in English national Examination in Indonesia. Lingua Scientia Jurnal Bahasa, 11(1), 145-160. DOI:10.21274/ls.2019.11.1.145-160

Krathwohl, D. R. (2002). A Revision of Bloom's Taxonomy: An Overview. Theory into Practise, 41(4), 212-264.

Mishra, R., \& Kotecha, K. (2016). Are we there Yet! Inclusion of higher order thinking skills (HOTs) in assessment. Journal of Engineering Education Transformations, 0(0), 2-5. https://doi.org/10.16920/jeet/2016/v0i0/85686

Mahfuzah, Afifatul, Jufri \& Fitrawati. (2019). An Analysis of students' ability to answerreading questions with HOTS.Journal of English Language Teaching, 8(1), 71 - 81. https://doi.org/10.24036/jelt.8i1.103222

Moore, B., \& Stanley, T. (2013). Critical thinking and formative assessments: Increasing the rigor in your classroom. New York: Routledge.

Richards, J. C., \& Lockhart, C. (2007). Reflective Teaching in Second Language Classrooms: Cambridge University Press.

Toni A., \& Parse, F. (2013). The status of teacher's questions and students' responses: The case of an EFL Class. Academy Publisher, 4(3), 564- 569. DOI:10.4304/jltr.4.3.564-569.

Tsui, A.B. M. (1995). Introducing classroom interaction. London: Penguin.

Walsh, S. (2013). Classroom discourse and teacher development: Edinburgh University Press.

Widodo, Tri dan Sri Kadarwati. (2013). Higher order thinking berbasis pemecahan masalah untuk meningkatkan hasil belajar berorientasi pembentukan karakter siswa. CakrawalaPendidikan. Vol. 42 (1). 161-171. 